\title{
Effect of acid treatment on the structure of sepiolite
}

\author{
A. YEBRA-RODRÍGUEZ ${ }^{1}$, J. D. MARTÍN-RAMOS ${ }^{2}$, F. DEL REY ${ }^{3}$, \\ C. VISERAS ${ }^{4}$ AND A. LÓPEZ-GALINDO ${ }^{1, *}$ \\ ${ }^{1}$ Instituto Andaluz de Ciencias de la Tierra (CSIC-UGR), Campus Fuentenueva, 18071 Granada, ${ }^{2}$ Departamento de \\ Mineralogía y Petrología, Campus Fuentenueva, 18071 Granada, ${ }^{3}$ Departamento de Química Inorgánica, Campus \\ Fuentenueva, 18071 Granada, and ${ }^{4}$ Departamento de Farmacia y Tecnología Farmacéutica, Facultad de Farmacia, \\ Universidade de Granada, Spain
}

(Received 17 December 2001; revised 7 January 2003)

\begin{abstract}
An $a b$ initio determination of the structure of sepiolite after acid treatment $(\mathrm{HCl}$ $0.5 \mathrm{~N}$ for $24 \mathrm{~h}$ ) was carried out using X-ray powder diffraction data. After acid treatment, the sections normal to the $a$ and $c$ axes presented discontinuities, $\sim 2.25 \AA$ wide, parallel to the (010) plane, with no electronic density maxima, thus suggesting that adjacent planes are joined by van der Waals-like residual links. Partial dissolution was detected on both octahedral and tetrahedral sheets, beginning by breaking the ribbons not along the edges, but in the centre, thus creating a $5.20 \times 6.79 \AA$ tunnel along the $a$ axis. By interrupting the tetrahedral sheet, this mechanism changes the phyllosilicate-like nature of the sepiolite to an inosilicate-like structure.
\end{abstract}

KEYWORDS: sepiolite structure, acid treatment, X-ray powder diffraction.

Sepiolite is a hydrated $\mathrm{Mg}$ phyllosilicate with fibrous morphology resulting from the molecular organization of an ideal unit $\mathrm{Si}_{12} \mathrm{O}_{30} \mathrm{Mg}_{8}(\mathrm{OH})_{4}$ $\left(\mathrm{OH}_{2}\right)_{4} \cdot 8 \mathrm{H}_{2} \mathrm{O}$. According to this formula, sepiolite contains in its structure: zeolitic and adsorbed water, four $\mathrm{H}_{2} \mathrm{O}$ molecules coordinated with bordering octahedral cations and hydroxyl groups at the centre of the 2:1 ribbons (Jones \& Galán, 1988; Galán \& Carretero, 1999, and references therein). Sepiolite has a high BET surface area that allows adsorption of water, polar liquids, ions and even molecules such as drugs or insecticides. Adsorption is due to the presence of active adsorption centres on sepiolite surfaces (oxygen atoms in the tetrahedral sheet, water molecules coordinated with the $\mathrm{Mg}^{2+}$ ions at the edge of the structure, and silanol groups caused by the break-up of $\mathrm{Si}-\mathrm{O}-\mathrm{Si}$ bonds).

* E-mail: alberto@ugr.es

DOI: $10.1180 / 0009855033830101$
Porosity measurements on sepiolite samples under different temperature and acid conditions have shown specific surface area, catalytic activity and sorptive capacity to be correlated to the previous treatment (Jiménez López et al., 1978; Vicente Rodríguez et al., 1994). The increase in specific surface area is attributed to porosity variations in the samples (Dandy \& Nadiye Tabbiruka, 1975). Dékány et al. (1999) reported the changes occurring in the arrangement of $\mathrm{Si}$ and $\mathrm{Al}$ atoms in the structure via ${ }^{29} \mathrm{Si}$ and ${ }^{27} \mathrm{Al}$ MASNMR analysis. Acid activation of sepiolite induces a partial dissolution of the structure, as reported in Rodríguez Reinoso et al. (1981), González et al. (1984) and Cornejo \& Hermosín (1986). The result of such treatment is a silica gel containing some impurities, whose fibrous morphology is very similar to that of the original sepiolite.

Nevertheless, although acid activation is well known, some of the changes occurring in the sepiolite structure are not fully understood. Control of the structural changes occurring in 
sepiolite during acid treatment could allow use of this clay in the manufacture of polymer-clay nanocomposites, where the clay particles (typically smectite) act as reinforcement in a polymer matrix. Nanoscale dispersion of a small amount (5 wt.\%) of the inorganic component optimizes the mechanical properties of the nanocomposite. The resulting material has improved properties as regards tensile modulus, tensile strength, heat distortion temperature, impact strength, water adsorption and thermal expansion coefficient (Kojima et al., 1993; Wang \& Pinnavaia, 1994; Lan et al., 1995, 1996; Krishnamoorti \& Giannelis, 1997; Wang \& Pinnavaia, 1998).

The aim of this study is the $a b$ initio determination of sepiolite structure after acid treatment on the basis of X-ray powder diffraction data, and comparison with that described in Brindley (1959) and Zvyagin (1967), who determined the space group according to systematic studies of extinction from a single fibre crystal based on electron diffraction patterns. Rautureau et al. (1972), Rautureau (1974), Rautureau and Tchoubar (1974) and Yucel et al. (1981) have refined the model based on electron diffraction data.

\section{Material and methods}

The sepiolite sample was obtained from a quarry mined by TOLSA (Spain) in Yunclillos (Toledo, Tajo Basin, Spain). Five grams of sepiolite ground to $40 \mu \mathrm{m}$ were treated in $100 \mathrm{ml}$ of $0.5 \mathrm{~N} \mathrm{HCl}$ solution at $25^{\circ} \mathrm{C}$ for $48 \mathrm{~h}$. The resulting solid was washed until no chloride anions could be detected, and dried at $45^{\circ} \mathrm{C}$. X-ray diffraction (XRD) was carried out in a Philips PW 1710, using $\mathrm{Cu}-\mathrm{K} \alpha$ radiation, automatic slit and graphite monochromator, and operated at $40 \mathrm{mV}, 40 \mathrm{kV}$ intensity, in the $2 \theta$ range between 5 and $60^{\circ}$, with a step size of $0.02^{\circ}$, and $4 \mathrm{~s}$ counting time at fixed $2 \theta$ values. The PLV $^{\odot}$ program (Martín Ramos, 1990) was used to subtract background by applying a roller with a $4^{\circ} 2 \theta$ curvature radius. Contact points with the XRD diagram were then linked using a cubic spline function.

The space group was considered to be Pnan, the initial unit-cell values were: $a=5.255 \AA ; b=$ $26.97 \AA ; c=13.50 \AA$ and the channel size $6.74 \times 13.40 \AA$. Observed conditions limiting possible reflections were: $h k 0: h+k=2 n ; h 0 l: h$ $=2 n ; 0 k l: k+l=2 n$, according to the Pnan crystallographic group.
The EXPO program (EXTRACTION and EXPO, Altomare et al., 1995) was used for $0^{\circ} 2 \theta$ correction, Lorentz polarization and multiplicity corrections. $\mathrm{K \alpha}_{2}$ stripping was carried out using a 3 bar histogram. Profiles were adjusted to the best model (Pearson VII distribution function) and then deconvolution of peaks and extraction of $|\mathrm{F|}|_{H K L}$ were carried out. 266 reflections with the highest $\mathrm{E}$ values (normalized structure factors) and 68 with the lowest values were used from a total of 1063 possible reflections in the studied sphere. The SIRPOW module was then used for structure determination and unit-cell refinement. The electronic density map was then calculated and the structure obtained. After 60 cycles the program adjusted suitable values for the $a, b$ and $c$ axes regardless of those previously assigned. The global temperature factor $\left(U_{\mathrm{eq}}=0.05\right)$ was obtained from the Wilson plot. Calculations of bond lengths and angles in tetrahedra and octahedra were made and compared with the sepiolite structure described in the literature.

The final drawings were designed using the XP module of the SHELXTLTM program (Sheldrick, 1989).

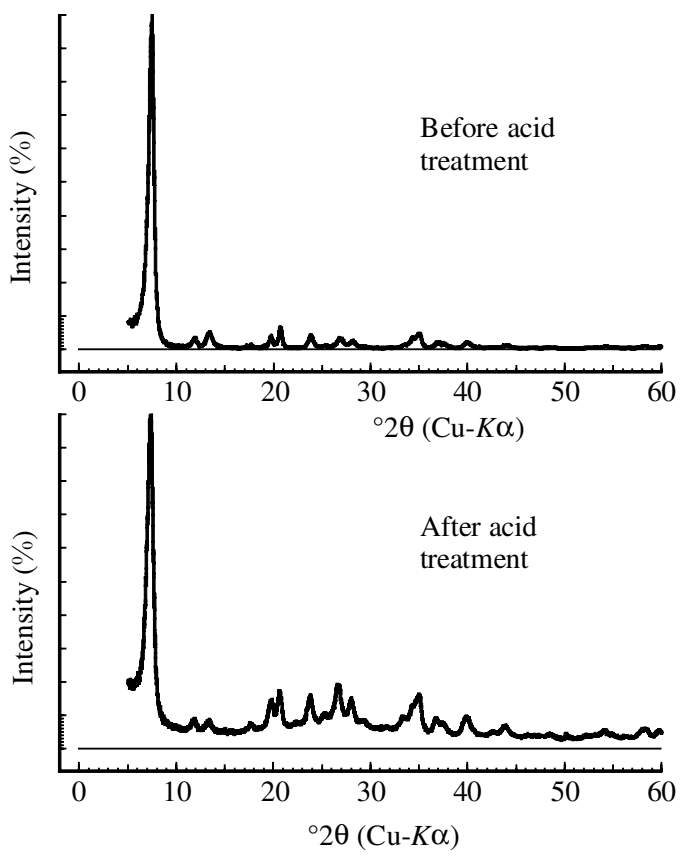

FIG. 1. XRD patterns of sepiolite before and after acid treatment, the latter showing a relative increase in the background. 


\section{RESULTS AND DISCUSSION}

The prototype model of the sepiolite structure after acid treatment obtained using the SIRPOW module (Altomare et $a l .$, 1995) and recurrent direct methods, at first sight seems different from the original structure.

Figure 1 shows the XRD patterns of sepiolite before and after acid treatment. The positions of the peaks are the same in both patterns. Only some peaks differ from one diagram to the other in terms of relative intensity. According to González et al. (1984) and Cornejo \& Hermosín (1986) the X-ray

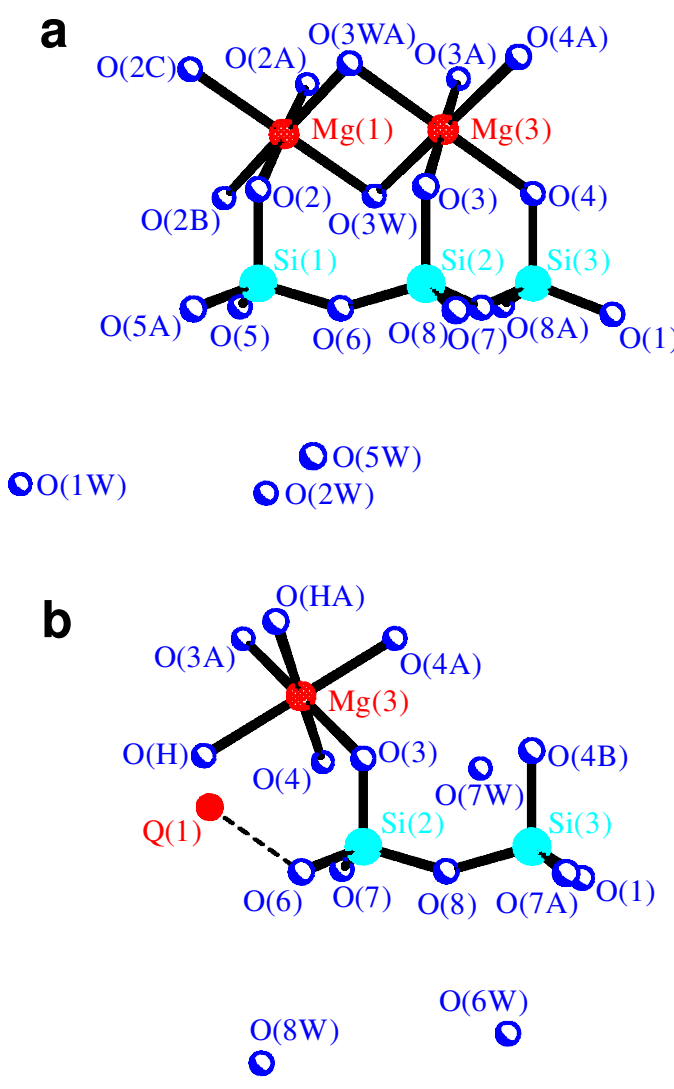

FIG. 2. Atomic positions in the asymmetric unit of sepiolite before (a) and after (b) acid treatment. Oxygen atoms taking part in the zeolitic water of the channels are denoted as W. For easier interpretation of the figures, atoms generated by symmetry are also included, according to the following: $\mathrm{O}(2 \mathrm{~A}), \mathrm{O}(3 \mathrm{~A})$, $\mathrm{O}(4 \mathrm{~A}), \mathrm{O}(\mathrm{HA})$ and $\mathrm{O}(3 \mathrm{WA})=-x, y, 0.5-z ; \mathrm{O}(2 \mathrm{~B})$ $=x,-y,-0.5+z ; \mathrm{O}(2 \mathrm{C})=-x,-y, 1-z ; \mathrm{O}(4 \mathrm{~B})$ and $\mathrm{O}$ $(7 \mathrm{~A})=x, y, 1+z ; \mathrm{O}(5 \mathrm{~A})=x,-y, 0.5+z ; \mathrm{O}(8 \mathrm{~A})=x, y$, $z-1$. pattern of sepiolite after acid treatment shows a larger amount of amorphous phase, as a result of the partial dissolution of the structure. Nevertheless, the amorphous phase was eliminated together with

TABLE 1. Atomic co-ordinates and occupancy of each atom in the asymmetric unit of sepiolite according to Brindley (1959). Oxygen atoms corresponding to water in the channels are denoted with W.

\begin{tabular}{lcccc}
\hline Atom & $x$ & $y$ & $z$ & $\begin{array}{r}\text { Maximum } \\
\text { occupancy }\end{array}$ \\
& & & & 1.00 \\
$\mathrm{Si}(1)$ & 0.208 & 0.028 & 0.562 & 1.00 \\
$\mathrm{Si}(2)$ & 0.208 & 0.140 & 0.562 & 1.00 \\
$\mathrm{Si}(3)$ & 0.208 & 0.196 & 0.062 & 0.50 \\
$\mathrm{Mg}(1)$ & 0.000 & 0.028 & 0.250 & 0.50 \\
$\mathrm{Mg}(3)$ & 0.000 & 0.140 & 0.250 & 0.50 \\
$\mathrm{O}(1)$ & 0.250 & 0.250 & 0.062 & 1.00 \\
$\mathrm{O}(2)$ & 0.084 & 0.028 & 0.562 & 1.00 \\
$\mathrm{O}(3)$ & 0.084 & 0.140 & 0.562 & 0.50 \\
$\mathrm{O}(4)$ & 0.084 & 0.196 & 0.062 & 1.00 \\
$\mathrm{O}(5)$ & 0.240 & 0.000 & 0.312 & 1.00 \\
$\mathrm{O}(6)$ & 0.240 & 0.084 & 0.562 & 0.50 \\
$\mathrm{O}(7)$ & 0.240 & 0.168 & 0.312 & 0.50 \\
$\mathrm{O}(8)$ & 0.240 & 0.168 & 0.812 & 1.00 \\
$\mathrm{O}(1 \mathrm{~W})$ & 0.500 & -0.172 & 0.250 & \\
$\mathrm{O}(2 \mathrm{~W})$ & 0.500 & 0.015 & 0.250 & \\
$\mathrm{O}(3 \mathrm{~W})$ & 0.084 & 0.084 & 0.062 & \\
$\mathrm{O}(5 \mathrm{~W})$ & 0.417 & 0.084 & 0.916 & \\
& & & & \\
\hline
\end{tabular}

TABLE 2. Atomic co-ordinates and occupancy of each atom in the asymmetric unit of sepiolite after acid treatment. Oxygen atoms corresponding to water in the channels are denoted with $\mathrm{W}$.

\begin{tabular}{lllll}
\hline Atom & $x$ & $y$ & $z$ & $\begin{array}{l}\text { Maximum } \\
\text { occupancy }\end{array}$ \\
\hline
\end{tabular}

\begin{tabular}{lllll}
\hline $\mathrm{Si}(2)$ & 0.208 & 0.140 & 0.562 & 1.00 \\
$\mathrm{Si}(3)$ & 0.208 & 0.196 & 1.062 & 1.00 \\
$\mathrm{Mg}(3)$ & 0.000 & 0.140 & 0.250 & 0.50 \\
$\mathrm{Q}(1)$ & 0.159 & 0.025 & 0.462 & 1.00 \\
$\mathrm{O}(1)$ & 0.250 & 0.250 & 1.062 & 0.50 \\
$\mathrm{O}(3)$ & 0.091 & 0.140 & 0.562 & 1.00 \\
$\mathrm{O}(4)$ & 0.084 & 0.196 & 0.062 & 1.00 \\
$\mathrm{O}(6)$ & 0.240 & 0.084 & 0.562 & 1.00 \\
$\mathrm{O}(7)$ & 0.240 & 0.168 & 0.312 & 1.00 \\
$\mathrm{O}(8)$ & 0.240 & 0.168 & 0.812 & 1.00 \\
$\mathrm{O}(\mathrm{H})$ & 0.084 & 0.084 & 0.062 & 1.00 \\
$\mathrm{O}(6 \mathrm{~W})$ & 0.456 & 0.207 & 0.914 & 1.00 \\
$\mathrm{O}(7 \mathrm{~W})$ & 0.095 & 0.265 & 0.540 & 1.00 \\
$\mathrm{O}(8 \mathrm{~W})$ & 0.500 & 0.104 & 0.250 & 0.50 \\
& & & & \\
\hline
\end{tabular}


TABLE 3. Bond lengths $(\AA)$ and angles $\left({ }^{\circ}\right)$ between atoms in the tetrahedra of the asymmetric unit of sepiolite according to Brindley (1959) and sepiolite after acid treatment.

(a) Sepiolite (Brindley (1959)

\begin{tabular}{|c|c|c|c|c|}
\hline & Bond length & Angle with $\mathrm{O}(2)$ & Angle with $\mathrm{O}(5)$ & \\
\hline $\mathrm{Si}(1)-\mathrm{O}(2)$ & 1.674 & & & \\
\hline $\mathrm{Si}(1)-\mathrm{O}(5)$ & 1.576 & 105.9 & & \\
\hline \multirow[t]{2}{*}{$\mathrm{Si}(1)-\mathrm{O}(6)$} & 1.571 & 106.0 & 112.7 & \\
\hline & Bond length & Angle with $\mathrm{O}(3)$ & Angle with $\mathrm{O}(6)$ & Angle with $\mathrm{O}(7)$ \\
\hline $\mathrm{Si}(2)-\mathrm{O}(3)$ & 1.674 & & & \multirow{8}{*}{113.0} \\
\hline $\mathrm{Si}(2)-\mathrm{O}(6)$ & 1.571 & 106.0 & & \\
\hline $\mathrm{Si}(2)-\mathrm{O}(7)$ & 1.576 & 105.9 & 112.7 & \\
\hline \multirow[t]{2}{*}{$\mathrm{Si}(2)-\mathrm{O}(8)$} & 1.576 & 105.9 & 112.7 & \\
\hline & Bond length & Angle with $\mathrm{O}(1)$ & Angle with $\mathrm{O}(4)$ & \\
\hline $\mathrm{Si}(3)-\mathrm{O}(1)$ & 1.563 & & & \\
\hline $\mathrm{Si}(3)-\mathrm{O}(4)$ & 1.674 & 111.3 & & \\
\hline $\mathrm{Si}(3)-\mathrm{O}(7)$ & 1.576 & 110.3 & 105.9 & \\
\hline \multicolumn{5}{|c|}{ (b) Sepiolite after acid treatment } \\
\hline & Bond length & Angle with $\mathrm{O}(3)$ & Angle with $\mathrm{O}(6)$ & Angle with $\mathrm{O}(7)$ \\
\hline $\mathrm{Si}(2)-\mathrm{O}(3)$ & 1.584 & & & \multirow{7}{*}{113.1} \\
\hline $\mathrm{Si}(2)-\mathrm{O}(6)$ & 1.560 & 106.1 & & \\
\hline $\mathrm{Si}(2)-\mathrm{O}(7)$ & 1.571 & 106.0 & 112.4 & \\
\hline \multirow[t]{2}{*}{$\mathrm{Si}(2)-\mathrm{O}(8)$} & 1.571 & 106.0 & 112.4 & \\
\hline & Bond length & Angle with $\mathrm{O}(1)$ & & \\
\hline $\mathrm{Si}(3)-\mathrm{O}(1)$ & 1.553 & & & \\
\hline $\mathrm{Si}(3)-\mathrm{O}(8)$ & 1.571 & 110.1 & & \\
\hline
\end{tabular}

the background and therefore was not taken into account in the subsequent calculations.

Figure 2 shows the asymmetric unit of sepiolite designed from the XRD data of Brindley (1959) and that obtained after acid treatment. Oxygen atoms created by symmetry operations have been added in order to close octahedral and tetrahedral coordination polyhedra. The resulting atomic coordinates for each atom are shown in Table 1 (sepiolite before acid treatment) and Table 2 (sepiolite after acid treatment). Tables 3 and 4 contain the results of lengths and angles for tetrahedra and octahedra, respectively, in both models.

The bond length measured between $\mathrm{O}(4)$ and $\mathrm{O}(6 \mathrm{~W})$ on sepiolite after acid treatment $(2.7-3 \AA)$ shows that $\mathrm{O}(6 \mathrm{~W})$ corresponds to zeolitic water, as this distance is that typically found in an $\mathrm{O}-\mathrm{H}-\mathrm{O}$ hydrogen bond. Separation was $2.96 \AA$ between zeolitic water molecules and $2-2.2 \AA$ between electronic density maxima in the old channels $\mathrm{O}(8 \mathrm{~W}), \mathrm{O}(6 \mathrm{~W})$ and $\mathrm{O}(7 \mathrm{~W})$. These distances are incompatible, so there can only be one of these atoms in each unit cell. This in turn means that the true unit cell is a super-cell along the $a$ axis, two or three times the length of the original cell. These atoms are co-ordinated with the $\mathrm{O}(4)$ of the octahedral sheets (with a separation of $2.78 \AA$ ) or with the basal oxygen atoms of the tetrahedra $\mathrm{O}(8)$ (with a separation of $3.11-3.14 \AA$ ), which are typical distances between two oxygen atoms linked by a hydrogen bond. The residual electronic density peak observed at $\mathrm{Q}(1)$ is located $2.00 \AA$ from $\mathrm{O}(6)$ 
TABLE 4. Bond lengths $(\AA)$ and angles $\left({ }^{\circ}\right)$ between atoms in the octahedra of the asymmetric unit of sepiolite according to Brindley (1959) and sepiolite after acid treatment.

(a) Sepiolite (Brindley (1959)

\begin{tabular}{lccc}
\hline & Bond length & Angle with $\mathrm{O}(2)$ & \\
\hline $\mathrm{Mg}(1)-\mathrm{O}(2)$ & 1.994 & & \\
$\mathrm{Mg}(1)-\mathrm{O}(3 \mathrm{~W})$ & 2.131 & 94.5 & \\
\hline & Bond length & Angle with $\mathrm{O}(3)$ & Angle with $\mathrm{O}(4)$ \\
\hline $\mathrm{Mg}(3)-\mathrm{O}(3)$ & 1.994 & & \\
$\mathrm{Mg}(3)-\mathrm{O}(4)$ & 2.131 & 94.5 & \\
$\mathrm{Mg}(3)-\mathrm{O}(3 \mathrm{~W})$ & 2.131 & 94.5 & Angle with $\mathrm{O}(4)$ \\
$($ b) Sepiolite after acid treatment & & \\
& Bond length & Angle with $\mathrm{O}(3)$ & \\
\hline $\mathrm{Mg}(3)-\mathrm{O}(3)$ & 2.048 & & 89.8 \\
$\mathrm{Mg}(3)-\mathrm{O}(4)$ & 2.124 & 92.8 & \\
$\mathrm{Mg}(3)-\mathrm{O}(\mathrm{H})$ & 2.124 & & \\
\hline
\end{tabular}

and $2.83 \AA$ from $\mathrm{O}(\mathrm{H})$, which we interpret as residual $\mathrm{Mg}$ from partial degradation of the octahedral sheet, compensating the charge deficit in the free oxygen atoms $\mathrm{O}(6)$ at the edge of the tetrahedra. This break-up explains the increase in BET surface area and the chemical activity of activated sepiolites reported in the literature (Myriam et al., 1998; Balci, 1999; Dékány et al., 1999; Li \& Luo, 2001; Jin et al., 2001).

Figure 3 shows a section normal to the $c$ axis in both sepiolite structures, in which projections can be seen what apparently represent (common
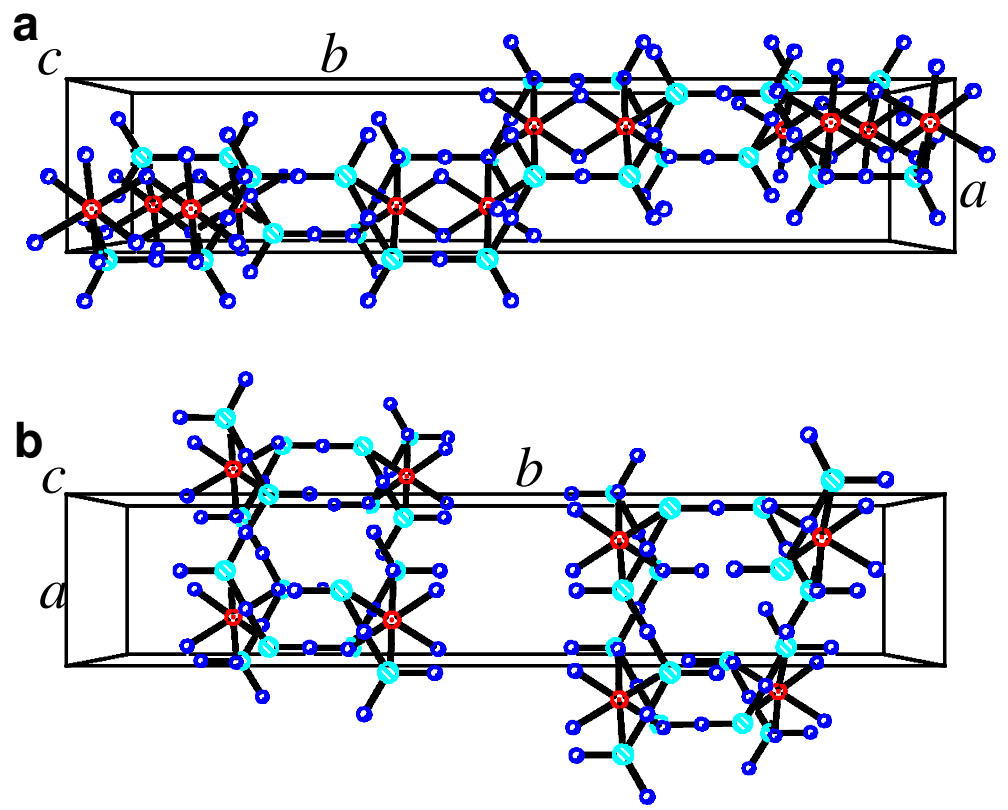

FIG. 3. Crystal-structure view of sepiolite from the $c$ axis before (a) and after (b) acid treatment, where the $a b$ plane is shown. 
phyllosilicate-like) ditrigonal basal oxygen atoms. The $5 \AA$ diameter rings do not belong to the basal rings of the tetrahedra (as it might seem), but are a projection of all the oxygen atoms on the $c b$ plane. That is, not all the oxygen atoms forming the same ring are at the same height along the $c$ axis.

The section normal to the $b$ axis in sepiolite after acid treatment (Fig. 4) shows ribbons probably corresponding to $\mathrm{T}-\mathrm{O}-\mathrm{T}$ chains without orthogonal correspondence to any of the axes. Both tetrahedral and octahedral inversion can be observed. Both layers are at different depths along the $b$ axis, creating a warped structure.

Figure 5 shows sepiolite structure in a section normal to the $a$ axis. Some electronic density maxima can be seen at the centre of the zeolitic water channels after acid treatment. Apart from the ribbons, other electronic density maxima are present, corresponding to strongly linked charge groups that compensate the deficits in the $\mathrm{T}-\mathrm{O}-\mathrm{T}$ skeletons (water molecules, $\mathrm{Ca}^{2+}, \mathrm{K}^{+}$or $\mathrm{Mg}^{2+}$ from the degradation of the octahedral sheet, etc). $\mathrm{Si}^{4+}$ from the tetrahedral sheet remains as free silica (Vicente Rodríguez et al., 1994). The size of the new channels is $\sim 15 \times 6.5 \AA$, and they form a zigzag pattern linked by the vertices.

The section normal to $c$ (Fig. 3), and particularly that normal to $a$ (Fig. 5) show discontinuities parallel to the (010) plane $(\sim 2.25 \AA$ in width $)$ with no electronic density maxima. This is a zone with little or no charge density, and the union between adjacent planes occurs by van der Waalslike residual links. The sheet is electronically neutral and charge density is very high in the hollows, so the elements are strongly linked. Partial dissolution of the octahedral and tetrahedral sheets begins by breaking the ribbons not at the edges, but at the centre, creating a $5.20 \times 6.79 \AA$ tunnel along the $a$ axis. The $\mathrm{T}-\mathrm{O}-\mathrm{T}$ skeleton maintains the symmetry of the original space group, but particles in the channels reorganize into a larger range (that is, particles disorder), which means that the asymmetric unit is larger too, and the $a$ axis two or three times its original size.
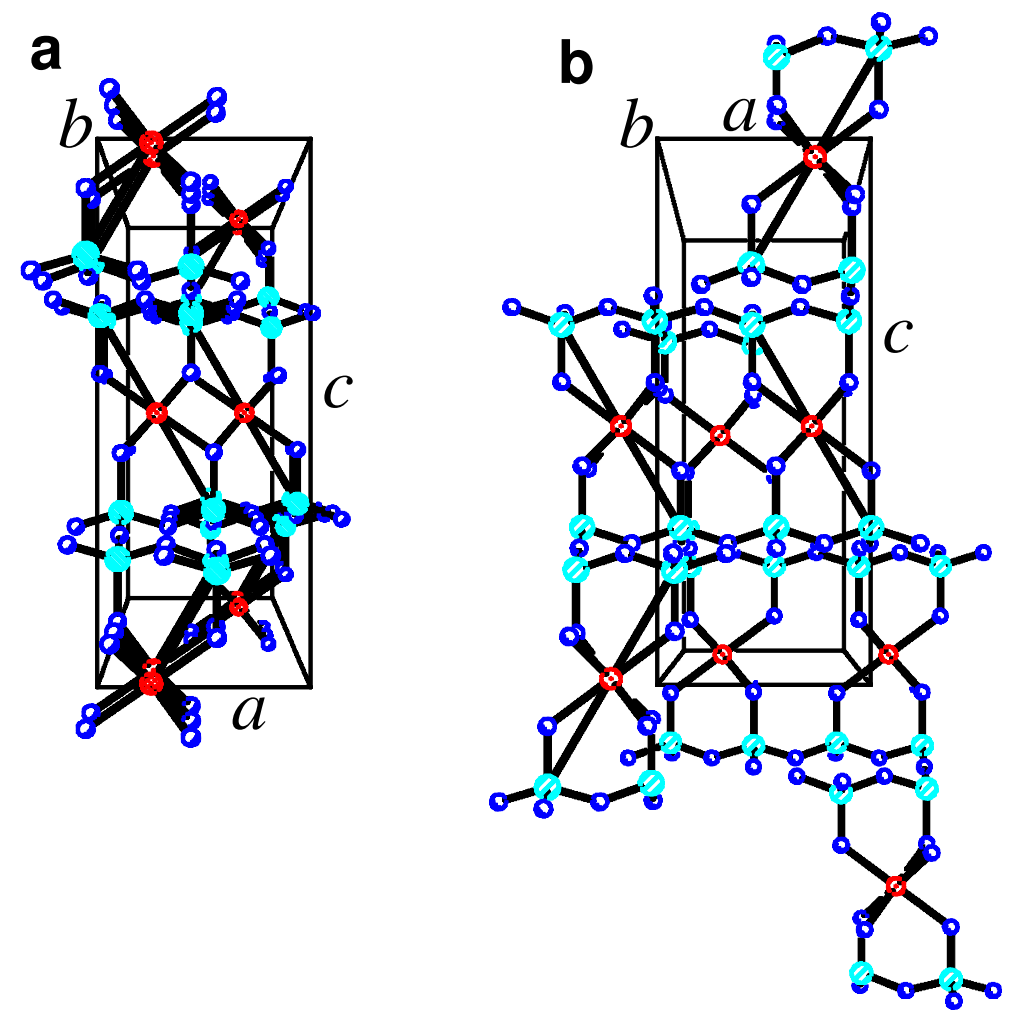

FIG. 4. Crystal-structure view of sepiolite from the $b$ axis before (a) and after (b) acid treatment, where the $a c$ plane is shown. 


\section{a}

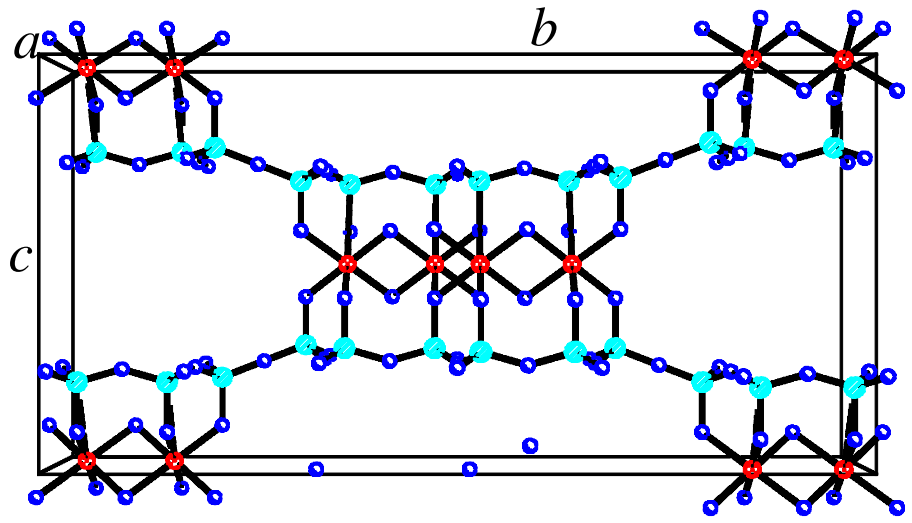

b

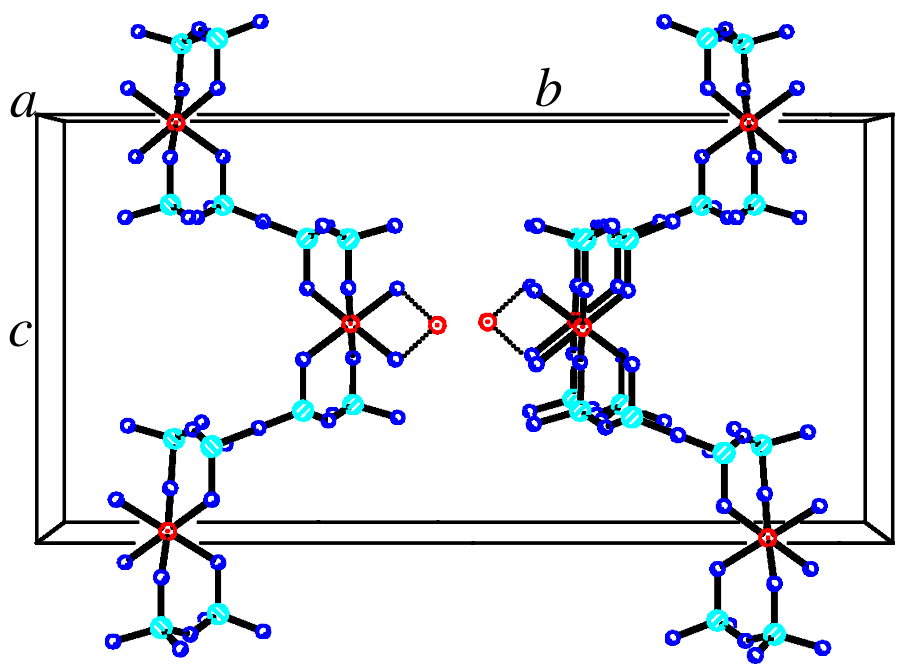

FIG. 5. Crystal-structure view of sepiolite from the $a$ axis before (a) and after (b) acid treatment, where the $b c$ plane is shown.

The space group and crystal size do not change after acid treatment, but the unit cell changes slightly: $c$ increases to $13.54 \AA$, and $b$ and $a$ reduce to $26.76 \AA$ and $5.24 \AA$, respectively.

\section{CONCLUSIONS}

The structure of sepiolite after acid treatment has the space group Pnan, the same as that described for untreated sepiolite in the literature, but acid treatment produces a very strong discontinuity in both tetrahedral and octahedral sheets, causing the sepiolite to change to an inosilicate-like structure.

Dissolution of the layers starts at the centre of the chains, creating $5.20 \times 6.79 \AA$ discontinuities along the $a$ axis. The activity and cation exchange capacity are due to $\mathrm{Mg}^{2+}$ ions from partial degradation of the octahedral sheet weakly linked to the free oxygen atoms in the tetrahedra.

\section{ACKNOWLEDGMENTS}

Prof. Dr. Emilio Galán and another anonymous referee are gratefully acknowledged for their valuable comments and suggestions. This research was supported by Project DGI-BTE2000-0777 (MCYT, Spain) and Group RNM-0179 of the Junta de Andalucía (Spain). 


\section{REFERENCES}

Altomare A., Burla M.C., Cascarano G., Giacovazzo C., Guagliardi A., Moliterni A.G.G. \& Polidori G. (1995) EXTRA: a Program for extracting Structure-Factor Amplitudes from Powder Diffraction Data. Journal of Applied Crystallography, 28, 842-846.

Balci S. (1999) Effect of heating and acid pre-treatment on pore size distribution of sepiolite. Clay Minerals, 34, $647-655$.

Brindley G.W. (1959) X-ray and electron diffraction data for sepiolite. American Mineralogist, 44, $495-500$.

Cornejo J. \& Hermosín M.C. (1986) Efecto de la temperatura en la acidez superficial del producto obtenido por tratamiento ácido de la sepiolita. Boletín de la Sociedad Española de Mineralogía, 9, $135-138$.

Dandy A.J. \& Nadiye-Tabbiruka M.S. (1975) The effect of heating in vacuo on the microporosity of sepiolite. Clays and Clay Minerals, 23, 428-430.

Dékány I., Turia L., Fonseca A. \& Nagy J.B. (1999) The structure of acid treated sepiolites: small-angle X-ray scattering and multi MAS-NMR investigations. Applied Clay Science, 10, 141-160.

Galán E. \& Carretero M.I. (1999) A new approach to compositional limits for sepiolite and palygorskite. Clays and Clay Minerals, 47, 399-409.

González L., Ibarra L.M., Rodríguez A., Moya S. \& Valle F.J. (1984) Fibrous silica gel obtained from sepiolite by $\mathrm{HCl}$ attack. Clay Minerals, 19, 93-98.

Jiménez López A., López González J.D., Ramírez Sáenz A., Rodríguez Reinoso F., Valenzuela Calahorro C. \& Zurita Herrera L. (1978) Evolution of surface area in a sepiolite as a function of acid and heat treatments. Clay Minerals, 13, 375-385.

Jin S., Yang W. \& Tang M. (2001) Study of sepiolite surface modification by acidic processing. Huagong Xiandai/Modern Chemical Industry, 21, 26-28.

Jones B.F. \& Galán E. (1988) Sepiolite and palygorskite. Pp. 631-674 in: Hydrous Phyllosilicates (exclusive of micas) (S.W. Bailey, editor). Reviews in Mineralogy, 19, Mineralogical Society of America, Washington, D.C.

Kojima Y., Usuki A., Kawasumi M., Okada A., Fukushima Y., Kurauchi T. \& Kamigaito O. (1993) Mechanical properties of nylon 6-clay hybrid. Journal of Material Research, 8, 1185-1189.

Krishnamoorti R. \& Giannelis E.P. (1997) Rheology of end-tethered polymer layered silicate nanocomposites. Macromolecules, 30, $4097-4102$.

Lan T., Kaviratna P.D. \& Pinnavaia T.J. (1995) Mechanism of clay tactoid exfoliation in epoxy-clay nanocomposites. Chemistry of Materials, 7, $2144-2150$.

Lan T., Kaviratna P.D. \& Pinnavaia T.J. (1996) Epoxy self-polymerisation in smectite clays. Journal of Physics and Chemistry of Solids, 57, $1005-1010$.

Li S.J. \& Luo L.T. (2001) Modification of sepiolite and its application in supported catalysts. Huagong Xiandai/Modern Chemical Industry, 21, 21 -25.

Martín Ramos J.D. (1990) POLVO. Programa de control y análisis del difractómetro de rayos $X$. Depósito Legal M-11719.

Myriam M., Suarez M. \& Martin-Pozas J.M. (1998) Structural and textural modifications of palygorskite and sepiolite under acid treatment. Clays and Clay Minerals, 46, 225-231.

Rautureau M. (1974) Analyse structurale de la sepiolite par microdiffraction electronique. These Universitè d'Orleans, France, 89 pp.

Rautureau M. \& Tchoubar C. (1974) Precisions concernant l'analyse structurale de la sepiolite par microdiffraction electronique. Comptes Rendus de l'Académie des Sciences de Paris, 278B, 25-28.

Rautureau M., Tchoubar C. \& Mering J. (1972) Analyse structurale de la sepiolite par microdiffraction electronique. Comptes Rendus de l'Académie des Sciences de Paris, 274C, 269-271.

Rodríguez Reinoso F., Ramírez Saenz A., López González J.D., Valenzuela Calahorro C. \& Zurita Herrera L. (1981) Activation of a sepiolite with dilute solutions of $\mathrm{HNO}_{3}$ and subsequent heat treatment. Clay Minerals, 16, 315-323.

Sheldrick G.M. (1989) SHELXTL-Plus. Program for the Solution of Crystal Structures. Release 3.4. University of Götingen, Germany.

Vicente Rodríguez M.A., López González J.D. \& Bañares Muñoz M.A. (1994) Acid activation of a Spanish sepiolite: physicochemical characterisation, free silica content and surface area of products obtained. Clay Minerals, 29, 361-367.

Wang M.S. \& Pinnavaia T.J. (1994) Clay-polymer nanocomposites formed from acidic derivatives of montmorillonite and an epoxy resin. Chemistry of Materials, 6, $468-474$.

Wang Z. \& Pinnavaia T.J. (1998) Nanolayer reinforcement of elastomeric polyuretane. Chemistry of Materials, 10, 3769 -3771.

Yucel A.M., Rautureau M., Tchoubar D. \& Tchoubar C. (1981) Calculation of the X-ray powder reflection profiles of very small needle-like crystals. II. Quantitative results on Eskisehir sepiolite fibers. Journal of Applied Clay Science, 14, 431 -454.

Zvyagin B.B. (1967) Electron Diffraction Analysis of Clay Mineral Structures. Plenum Press, New York. 